\title{
SIMION BĂRNUŢIU - PIONEER IN THE DEVELOPMENT OF THE LAW SCIENCES AND OF THE LEGAL EDUCATION IN ROMANIA
}

\author{
Professor Marţian IOVAN, PhD \\ "Vasile Goldiş" Western University of Arad \\ Email: iovanm@uvvg.ro
}

(Received November 2017; Accepted December, 2017)

\begin{abstract}
The author analyses in this paper S. Bărnuţiu's contribution to the establishment of the legal education and to the development of the sciences of the Law in the Romanian area during the mid- $19^{\text {th }}$ century. Adept of the natural law philosophy, ardent promotor of human and people's rights, Bărnuţiu remains a personality of reference in the Romanians' history not only for being the political leader and ideologist of the Transylvanian 1848 Revolution, but also for establishing the legal education at the University of Iasi by inspiring himself from the curriculum of the profile schools of law from the Western Europe. Having a unitary conception on the law and on the history of law, considering the law from a systemic perspective, Bărnuţiu contributed into the edification of a modern, constitutional, and democratic State in the united Romanian Principalities.
\end{abstract}

Keywords: Barnutiu, human rights, history of law, legal education, Transylvanian scholars.

\section{Introduction}

Simion Barnutiu (1808 - 1864) was an important visionary politician in Transylvania and an outstanding scholar belong to the generation of patriot and revolution intellectuals of 1848, among which we mention George Bariţiu, August Treboniu Laurian, Timotei Cipariu, Alexandru Papiu Ilarian, Avram Iancu, and other. As first professor of law and of the philosophy of law in the Romanian area, $\mathrm{S}$. Barnutiu has the merits of being a pioneer (in the Transylvanian area) in the history of juridical sciences, of the political and juridical philosophy, of the anthropology, of the empiric psychology, logics, pedagogy, language science, dialectology, regarded as a school-creator - "Barnutiu's School".

Politically, Barnutiu was in the 1848 revolutionaries' front line, as main ideologist with democratic and humanist views, the leader of the Transylvanian revolutionaries (president of the Romanian Nation Committee). His work has been preponderant oral during that time $(1842-1849)$, consisting in speeches such as that in the Blaj Cathedral on May 2-14, 1848, which was reiterated afterwards and exposed in front of the Romanian's gathered on Câmpia Libertăţii (Freedom Plain) [1]. For the rest of his life, Barnutiu wrote academic manuals, being tenured professor at the University of Iaşi, manuals such as "Romanian Public Law", Iaşi, 1867, 472 p.; "Public Natural Law", Iaşi, 1879, 391 p.; "Private Natural Law", Iaşi, 
The Printing House of the Romanian Tribune, 1868, 300 p.; "The Pedagogy", Iaşi, 1870, 326 p.; "The Empiric Psychology and the Logics", Iaşi, 1871, 212 p.; "Natural Law", lithography, 168 p.; "The Etics", lithography, 90 p.; "The Logics", lithography, 88 p.; "The Metaphysics", lithography, 79 p.; "The Science of Virtue", lithography, parts I and II-a, $175 \mathrm{p}$. He published a large number of papers with humanist scientific contents in the journals of the time.

Both his written and oral works are loaded with new notions which were introduced in the Romanian philosophy and culture, to him being acknowledged the merits for expanding the philosophical vocabulary. He was the first teacher to give up Latin in teaching and to use Romanian instead, language which he developed up to the limits of making it able to express more nuanced the ideas and the thinking systems in the history of the universal culture and, especially, of the Europe of his times. An objective analyst appreciates that "the image of the most outstanding representative of a monumental generation, the one of the 1848 Romanian Revolution, emerges from his life and writings" [2]. In particular, Eugeniu Speranţia highlighted his philosophical and scientific merits, claiming that Barnutiu should be considered as "the true precursor of all those who cherish nowadays the studies of juridical Philosophy in Romania" [3].

Above all, Barnutiu was among the most endowed thinker and man of culture, who received and analysed the economic and social-political matters of his century, especially of those which the Romanians and the other nationalities of the Habsburg Empire faced with, finding solutions for them from the perspective of the rationalist and humanist philosophy, of the universal history and of other sciences of this time. His credo, his political beliefs during his entire life consisted in acknowledging the primordial value of the mankind, peoples' and communities natural law principles, the corollary of which is the Declaration of Human Rights issued during the French Revolution of 1789, and, further disseminated on a wider area in the European political and juridical culture. The people's, nationalities' and other human communities' rights emerge from and are substantiated on human natural rights. They have to triumph over the entire society and mankind in order to enthrone the justice and the civilisation benefits.

Barnutiu's life and works have been considered from various points of view, by more authors. Some put an emphasis on his practical works of revolutionary political activist, of coryphaeus of the Transylvanian revolution, reaching to the conclusion that Barnutiu's personality focused on the practical action, that he "a specifically political human being" [4]. The quintessence of his concepts and political program are included in his remarkable speech of Blaj, in 1848, which expresses his beliefs. All these exerted a deciding influence on the Romanian public opinion and on the Transylvanian Romanians national conscience. Therefore, the main merits of the Transylvanian scholar must be searched in his 
oral works, in his remarkable speeches. Barnutiu is considered one of the greatest Romanian orators of the $19^{\text {th }}$ century.

Other exegetes saw in the structure of his personality the shy person, inclined to meditation, with a polyvalent creative activity in the field of knowledge and culture, enjoying of a huge prestige. Thus, he "must be appreciated as the most noticeable thinker of the Transylvanian Romanian during the Revolution of 1848", as Radu Pantazi wrote [5].

In fact, the two views complete each other, as, for the first part of his life - until 1850, the action person, the Transylvanian patriot, expressed himself mostly in the political life, as democrat-revolutionary patriot for human and peoples' rights, capitalising the European culture and the benefits of the civilisation of his time. His works is predominantly oral, concretised in the famous speeches and manifestos [6]. After receiving the title of Doctor in Juridical Sciences at the University of Pavia, Italy in 1854, and being enrolled as tenured professor at the University of Iaşi, Barnutiu drafted academic course, published papers and studies, bringing remarkable contributions to the enrichment of the philosophy, sciences, culture, so that we can state that his monumental work is placed in the front line of the knowledge existing at mid- $19^{\text {th }}$ century in Romania, leaving its prints in developing the national and European culture up to our times.

This paper is analysing the contribution he brought in setting grounds for the beginnings of the political-juridical philosophy in the Romanian culture, the substantiation of his concept on the society organisation and development based on the promotion of human fundamental natural rights, and on the European level of the academic courses taught to the School of Law students, at the University of Iasi.

\section{The Politico-legal Philosophy - the Theoretical and Axiological Grounds for the Legal Sciences Development}

The philosophical training of the future Transylvanian scholar has been achieved starting with his studies at the Catholic High School of Carei, where he received education in the field of humanities, ethics, rhetoric, the Greek and Roman culture, the mythology and religion. Gradual learning of Latin, German, Hungarian and Italian eased his access to knowledge in various fields, specific for his time, and also to history, and classical culture. He has taken lectures of philosophy at Blaj during 1825-1826, further continued with the study of theology until 1829. He was very interested in the study of the history of philosophy and culture, being deeply marked by the classics' works such as Ovid, Tacitus, Livius, Plautus, Terentius, Cicero, Horace, by the great thinkers works starting with Plato up to Hegel, from Aristotle to Kant, from Socrates to Montesquieu, from the Eleatic School to the School of Natural and Historical Law. He has been influenced mostly by the works 
of the founders of the doctrine of the natural law and of its promoters - Hugo Grotius, Puffendorf, J.J. Rousseau, Im. Kant, Fr. Karl Savigny, Thomas Payne, J. Bentham, Destut de Tracy, Benjamin de Constant etc. As a convinced Kantian, he enriched his philosophical culture on the society, mankind and history by studying the works of the German professors, W. T. Krug, Gottfried Muller, and J. Beck.

The contact with defying social and national injustices expressed in Transylvania and in the empires of his time impressed and revolted him most deeply during his entire life. The philosophy of natural law, his intimate soul adhesion to the Declaration of Human Rights and to the principles of Kantian ethics helped him in the conception of his social and political philosophy, in finding the path to free and emancipate the persons who were enslaved economically, politically and spiritually by the feudal regimes, in issuing the direction to edify the future society at national, European scale and at a level of civilised humanity. His philosophical concept is focused on the person; his conception on the human beings is setting the concept on people and nation, on society and historical evolution of the mankind up to then and further on.

Both his philosophical works and writings have mostly been published after his death. The contribution of the Transylvanian thinker to the evolution of the Romanian philosophy and to the enrichment of the European one concretised in personal ideas and interpretations, in persuading demonstrations and value rankings from the perspective of rationalism and humanism in fields such as metaphysics, anthropology, nosology, political-juridical philosophy, logics, aesthetics, pedagogy. For the logic of this paper, we are interested which specifically are Barnutiu's philosophical principles, on which relied the issuing of his concept, his ideas on politics and law, as well as the drafting of the academic courses of public law, of private law, of pedagogy, logics, psychology and ethics.

The Transylvanian scholar claims with arguments and persuasively that the human being, as part of the nature, has by itself a specific nature, it has instincts, biological needs, necessities, and natural aspirations, dependent on his nature. As society members, as social beings, the men are endowed with "simple, natural rights which pre-exist to the positive law, they are primordial and superior in relation to the will of the ruling bodies". The society members truly justified claim the compliance with their natural rights. The juridical norms, the entire system of positive law have legitimacy only in compliance with mankind and nations natural law. In this regard, the philosopher writes that the natural law or the system of rational law "is the ground for the public law and for the entire political science" [7].

The civilised mankind in its entirety, the supreme court of the human reason claim that the natural rights are in compliance as necessity and in universal plan, in order to achieve justice, social peace, and general welfare for all and each person - 
individuals, human communities and nations. Mankind natural rights serve everywhere for orientation, for guidance for the political persons, for the legal bodies, for all taking decisions. There are no admissible facts, behaviour and opposite realities on behalf of the natural law, meaning despotism, slavery, colonialism, social and national inequity of all kind, the ruling based of the "right of force" and not on the force of the right, the un-nationalising of any ethnicity, etc. In this regard, in his famous manifesto called "A Shameful Bargaining and an Unjust Law", as response to the political decisions of the Hungarian aristocracy to generalize Hungarian in all State institutions, including in the Romanian schools, and, in doing so, to create a great nation with one language and one culture, and so causing the loss of the nationality for the Romanians in Transylvania, the patriot militant Barnutiu claims that "each man or people, or human being has the right to live in this world and consider itself as a person (jus subsistentiae personalis), to move its body strengths, its hands and feet, to earn some outer fortune and the powers of the soul, the meaning, the word, and so on, to earn the inner fortune: knowledge in all kinds of sciences, in arts, in foreign languages and of his mother tongue (jus libertatis personalis), and these rights are not more adequate for one than to another, or to one people more than to the other, but, in this regard, all persons and peoples are just as one, as from the beginning we are all alike and none has the privilege to kill another or to prevent another to act in order to achieve happiness according to the law (jus aequalitatis penalis)... each one has, by law, the duty to leave the other in peace, not only to let that one lives as long as it is given, but also to work free and within one's scope, to earn some fortune, without which one could not live at all or would live more animal than human life" [8]. It results from this text which is his attitude concerning the need to respect human and peoples' fundamental rights. The political-juridical philosophy, his contribution to the development of the sciences of public and private law rely on the strong persuasion that human rights must be respected by anyone, at anytime, at universal scale.

The form of State, which is Barnutiu's option with historical and philosophical arguments, is the Republic, resulted from citizens' agreement, from the social pact they concluded and from the need of continuous adjustment of the State and law institutional structure according to people's general will. The initial pact (social agreement) is submitted to changes each time the people asks for. The relations between individuals, between individuals and society, between citizens and the State may be harmonious, peaceful due to the fact that the power (potestas) belongs to the people and works in their favour, according to the laws. The State powers must be separated and cooperate between each other in order to accomplish the State purposes, the common welfare and the justices. The law means "the rule by which a rational harmony is to be set between the external freedoms for all 
mankind" [9]. The supreme principle of the law is defined, by Kantian inspiration, as follows: "Just is everything that is not against the biggest freedom, as much as possible" [10]. It is obvious the influence of the Kantian thinking and of the organic and historical ideas of the school of natural law representatives.

The society, the state, the institutions could also emerge in other ways than by concluding a legitimate social contract, thus being violated the principles of human nature and reasoning. Along peoples' history, many States emerged artificially, by terror and violence, by operations of force of the great powers, by various ingenious plots of usurping people's power etc. All kind of despotic, oligarchic, aristocratic, tyrant States have emerged, and their purposes and laws were in opposition to the natural human and peoples' rights, to the reasoning and civilised humanity. Such States cannot achieve the real rational purposes, legitimate in the idea of State; they breach the fundamental rights, so demeaning the humanity, the human dignity. Their power is artificial, against human nature and happiness; it is apart from peoples' will, being used in the interest of the power holders, of the power to enslave, to dominate the many. Just the opposite for the republic which is the State passing the laws (positive law) according to the principles of the social contract, by consulting the people; it is the State which achieves the idea of justice, it is a legitimate state with the rule of law, governed by the power of law. The main and natural body of the political power (of the potestas - as S.B. wrote) is the majority of civil society member and "this is created and it is incumbent to it by the pact of the union itself' [11].

The purpose of the republican State is triple: 1. The establishment of the required institutions to put into practice the law of justice - the positive law; 2. Ensuring its members' and State as a whole security; 3. Granting solicitude for the development of the industry, economy, sciences, education, morality, religion and of other human interests.

Barnutiu's option is for democracy, for the State guaranteeing the right for life and security for its members, for the prosperity for all its citizens, the equal entitlement to property and peoples' enlightening for all the society members without discrimination. The Transylvanian philosopher claims that justice completes the idea of law by that it means the "behaviour according to the law" [12]. The establishment of the social and national justice requires that the power must not become an artificial tool of the State, but to remain the people's body. Distancing the power from the people and acquiring it by despots, tyrants or oligarchs is the main source of stifling the State complying with the natural law, the morality and the mankind values. The Republic is the only State corresponding to the morality and humanity. The citizens living in it are submitted to the pact of the universal union and will (consensus omnium) and only in order to achieve the purposes of the State [13]. Such a democratic State is not possible in the feudal system, which is a 
society organised against nature, it is unjust, based on servitude, social and national exploitation, on hereditary inequity, a society with two social ranks - the people deprived of potestate (power) and the dominant class of the feudal nobility. The universal and reasonable principles of the human nature, such as guaranteeing the existence, the right for life, for ownership, the people's freedom and equality in front of the laws are constantly violated - which is against the "court of the humanity", the Transylvanian scholar claims with arguments. The human and peoples' fundamental rights are, in the same time, the humanity and mankind rights, they are rights emerging from the concept of human being, of human reason, being universally available and inalienable. The State able to guarantee for such rights - the Republic - does not rely on the "law of the force" but on the "force of the law", it is the rule of law, and not the despotic, monolithic State - which means "pluralism of interests, submitted to a unitary framework of juridical nature" [14] as P. Pandrea noticed justifiably. Thus, the Transylvanian thinker voiced the natural fundamental aspirations of a people, enslaved and exploited by another, and projected the political strategy of its liberation and emancipation, and issued the required legal framework for removing the status quo in Transylvania and for changing, at historical level, the status quo according to a new legal system build on the universal respect of fundamental human and peoples' rights.

As for the relations between the peoples, the nations and the other human communities, Barnutiu states the same principles of political thinking. He believes that these, as subjects of international law, must enjoy freedom, independence, sovereignty and self-determination. The peace on the European continent and in the whole world, each people's prosperity may only be guaranteed by respecting of all the involved ones of the natural rights of existence for each human being, each nation or people.

With such a philosophical, rationalist and humanist vision on the society and governance, on the human being and its rights, and, while being guided towards them as an active person, A. Plămădeală considers Barnutiu was the soul of the Transylvanians' movement around 1848 and the "Romanian conscience of his time" [15]. In addition to this idea, the eminent professor from Cluj, D.D. Roşca, emphasises the scholar's intellectual and ideological horizon of "European scope" and, so, highlights that "nevertheless, history has proven that the one, who anticipated with his concept the progress of the time in the world and on the Romanian ground, was the "Barnutiu, the idealist" [16].

\section{S. Bărnuţiu's Training and Academic Activity}

Bărnuţiu's education was guided by his family - his father being cantor and primary school teacher in the natal village and his mother was priest's daughter. His grandfather from this father's side was also priest. After concluding the 
primary school in Şimleu, in 1820, he was admitted to the High School in Careii Mari. The grounds for his erudition have been set in there. He studied the philosophy for a year and then the theology at Blaj, during $1825-1829$. He was appointed as teacher of philosophy at the secondary school at Blaj in 1830. A. Papiu - Ilarian stated that Bărnuţiu had introduced at Blaj the concept of natural law - "the law of nature" ever since 1831, and that, starting with 1834 he gave up teaching in Latin in favour of Romania. For the following years, he translated in German the famous scholar and man of culture W. T. Krug's legal works.

Due to his involvement in revolutionary activities against Romanians' unnationalisation, Blaj clerical despotism and social injustice, the authorities removed him from Blaj, and he enrolled as student to the (German) Academy of Law at Sibiu. Besides the classical humanist culture acquired there, he studies works of the modern illuminist thinkers such as Kant, Hegel, Fichte, Krug, B. Constant, Savigny etc. Following the revolutionary events of 1848 , where he participated as leader and main ideologist, he had to immigrate to Transylvania together with other revolutionary and patriot politicians. He arrived to Vienna in 1850 and he was admitted as student at the School of Law. He left for Pavia after three semesters in order to continue his legal studies which were crowned by the awarding of the Doctor in law title [17]. The topics of his dissertation comprised chapters and ideas of the philosophy of law, of human rights, of Roman and feudal law, of criminal law, of Austrian civil law, of ecclesiastic law, of political sciences, of legal and notarial proceedings, and statistics.

In 1854, as organizer of the education in Moldova, A. Treboniu - Laurian gave him a position in the high school education in Iaşi, where he taught logics, becoming in 1856 professor at the School of Letters and Law of the University of Iaşi, where he taught until the end of his life.

The subjects taught by Bărnuţiu were those comprised in the School curriculum, namely: Roman Law History and Institutions, Natural Law, Ethics, Esthetics, Domestic and External Public Law of Romania and constitutional Law, History of Philosophy, Pedagogy and practical activities [18]. He issued a course meant for his disciples for each of those subjects. The scientific contents, the ideas comprised in courses have been taken from the Western legal culture, especially from the German one, thus the students receiving a professional training specific for the midst of the $19^{\text {th }}$ century. The analysts of Bărnuţiu's didactic publications appreciate that the works were not original, but they were abridged translations [19], only some comments, case studies, personal examples being integrated and aiming for the national specificity, the exception being only the course of Romanians' Public Law.

Both during the time spent in Blaj (1831-1848), and in Iaşi (1854-1864), great Bărnuţiu's merit in the field of the didactic activity was that he selected and built a 
Iovan, M. (2017)

Simion Bărnuţiu - Pioneer in the development of the law sciences and of the legal education in Romania

top academic offer, undertaken from the practice of the Western Universities of that time, that he developed a Romanian Law consistent with the Roman Law history and institutions, that he contributed in the development of the Romanian legal vocabulary. He brought a thorough vision on the legal principles and categories, adjusting them to the national specificities; he capitalized the pedagogical sciences during the teaching and colloquium debates he had organized in order to achieve the best results in his students' education. He organized the practical activities, internships, for legally training his students' personality and he disseminated his legal ideas outside the university, and, in doing so, he influenced the public life, the Romanian State organization and, above all, the establishment of a unitary national law system meant to crown and legally certifies the principalities union. In such a perspective, Bărnuţiu appears to us as an original writer, as a School creator - "Bărnuţiu's School", in competition with the T. Maiorescu's one.

Accumulating a huge prestige as professor, scholar and man of culture not only in the academic environment but also in the wide public area, Bărnuţiu was about to be worshiped by the successive cohorts of students and alumni of the Law School of Iaşi. Their representatives took care to post-mortem publishing of his didactic papers, thus succeeding in the propagation of his ideas on the human rights in the Romanian cultural area.

Considering the history of the legal education and of the sciences of the Law in Romania, a comparative approach of the legal education contents by the mid- $19^{\text {th }}$ century with the education carried on nowadays, 150 years later, might be interesting. In this regard, after an introduction on the history of public law, "The Public Natural Law", Iaşi, 1870, Bărnuţiu's didactic paper, is structured in a first part named "Domestic Public Law", having 11 chapters on the definition, origin and purpose of the State, on the territory, citizens' ranks, weather influence, on the physical causes and moral strengths; on the origin and grounds of the political power; on the political power attributes and limitations; on the majesty rights; on the Constitution doctrine: the monarchy, the aristocracy, the democracy and the genuine republic; on the division of the powers in a State; on the constitutional monarchy and the representative political systems; on the administrative organization of the State and the governance. Topics on the right to peace and the law of war, on the means of intermediation and strengthening of a legal status between nations and European political balance are approached in the section called the "Ethnicities' Rights".

The course with the title of "Private Natural Law", Tipariulu Tribunei Române, 1868 , is an abridged translation of a didactic paper written by the German professor Rotteck, in which there are integrate personal completions consisting of comments, notes, examples, case studies. Bărnuţiu's credo, the spirit marking the course may 
be summarized in the idea that the positive law has as holy grounds the natural and rational law. In a democratic State - which is the natural option for Bărnuţiu, the law consistent with the human nature must rule; the political power must not be above the law but to comply with it, to be its servant. This way, Bărnuţiu aimed for the settlement on modern, democratic grounds of the Romanian State, resulted from the Principalities union.

His course of private law comprises seven chapters on the absolute natural law, on the hypothetic private law, on agreements, on the species of the treaties, on the right to joint action, on the society and family law.

Analyzing the curricula, the contents of the legal education of the University of Iaşi by the middle of the $19^{\text {th }}$ century, it results that they are compliant with those from the Western Universities and that he was involved in a process of integrating in the circuit and at the level of field education of the Western Europe. One of Transylvanian scholar's great merits consist precisely in this achievement, resulting the defining note of his personality: the man of the accomplished duty for his nation.

\section{Instead of Conclusions}

Besides S. Bărnuţiu's main merits, we have to emphasise those of practical order proved as 1848 revolutionary leader and ideologist for the Transylvanian Romanians, and also those ascertained in his scientific, didactic and cultural activity. In this regard, the Transylvanian revolutionary expressed himself with same plenitude while organizing and developing the education in Transylvania, but mostly in the Principality of Moldova. He is the person who established the legal education at the University of Iaşi, who decided the curriculum, who issued and taught the first courses of law, logics, psychology, ethics and pedagogy for the Law students, who was concerned by training his disciples through practical education. Adept of the natural law doctrine, having a credo and a total devotion for the establishment of the human rights in the human society, Bărnuţiu propagated a humanistic and rationalist philosophy of law which was to be at the grounds of the edification of a modern powerful State for the Romanians. The Legal order is to be the result of all citizens' consensus and not to admit any kind of discrimination. The State powers are to be subordinated to the laws and never the opposite has to occur.

As for the reform of the Romanian law, he considered that this should rely on the Roman law; the Romanians' law could not be anything but a continuation and an adjustment of the Roman law to the specific conditions of Romania. By the established School of Law, Bărnuţiu should be places in the Pantheon of the modern Romania creators. We can agree with Bogdan-Duică's statement in one of his writings, namely that: "Bărnuţiu means a new binding of our life to the Western 
Iovan, M. (2017)

Simion Bărnuţiu - Pioneer in the development of the law sciences and of the legal education in Romania

one" [20] In the same order of ideas, the biographer dr. I. Raţiu thought that Bărnuţiu can be considered as the most important Romanian writer in the field of jurisprudence of his time. In the same time, we have to highlight Bărnuţiu's role as precursor of legalism in Romania.

In 2018, when there are 210 years since the birth of the illustrious Transylvanian thinker, we may find out that the philosophical-juridical ideas and Barnutiu's vision on the world, society and human beings is entirely current, practically proving the anticipatory potential and the available European size of the historic changes of the present and the future.

\section{Bibliography}

1. Bariţiu, George, „Părţi alese din istoria Transilvaniei pe două sute de ani în urmă”, vol. III, Sibiu, 1891.

2. Bărnuţiu Simion, „Dreptulu publicu alu Românilor, Iaşi 1867.

3. Bărnuţiu, Simion, „Dreptulu naturale publicu”, Iaşi, 1879.

4. Bărnuţiu Simion, „Dreptulu naturale privatu”, Iaşi, 1868.

5. Bărnuţiu, Simion, „Pedagogia”, Iaşi. 1870.

6. Bărnuţiu, Simion, „Psiholologia empirică şi Logica”, Iaşi, 1871.

7. Bogdan-Duică, G., "Viaţa şi ideile lui Simion Bărnuţiu", Bucureşti: Cultura Naţională, 1924.

8. Chindriş, Ioan, „Simion Bărnuţiu. Suveranitate naţională şi integrare europeană”, ClujNapoca: Imprimeria „Ardealul” Cluj, 1998.

9. Goldiş, Vasile, „Simion Bărnuţiu”, în „Scrieri social-politice şi literare”, ediţie îngrijită de Mircea Popa şi Gheorghe Şora, Timişoare: Editura Facla, 1976, pp. 258260.

10. Iorga, Nicolae, „Simion Bărnuţ”, în „Oameni cari au fost”, Bucureşti: Editura pentru Literarură, 1967, pp.197-199. 1911.

11. Pandrea, Petre, „Filosofia politico-juridică a lui Simion Bărnuţiu”, Bucureşti: România Press, 2007.

12. Pantazi, Radu, „Simion Bărnuţiu”, în „Istoria filosofiei româneşti”, ediţia a II-a, vol. I, Editura Academiei R.S.R., 1985, pp. 340 - 363.

13. Pantazi, Radu, „Simion Bărnuţiu. Opera şi gândirea”, Bucureşti: Editura Ştiinţifică, 1967.

14. Plămădeală, Antonie, „Simion Bărnuţiu în epocă şi în vecii vecilor”, în „Dascăli de cuget şi simţire românească”, Bucureşti: Editura Institutului Biblic şi de Misiune a Bisericii Ortodoxe Române, 1981, pp. 317-320.

15. Roşca, D.D., „Europeanul Bărnuţiu”, în „Oameni şi climate”, Cluj, 1971, pp. 73-101.

\section{Notes}

[1] His famous speeches are kept, as lithography, at the Library of the Romanian Academy, and at the State Archives.

[2] Chindriş, Ioan, "Simion Bărnuţiu. National Sovereignty and European Integration", Cluj-Napoca, 1999, p.7. 
[3] Speranţia, Eugen, “Introducere în Filosofia Dreptului”, ediţia a II-a, Tipografia „Cartea Românească” din Cluj, Sibiu, 1944, p. 262.

[4] Pandrea, Petre, „Filosofia politico-juridică a lui Simion Bărnuţiu”, Bucureşti: România Press, 2007, p.158.

[5] Pantazi, Radu, „Simion Bărnuţiu. Opera şi gândirea”, Bucureşti:Editura Ştiinţifică, 1967, p. 254.

[6] The most important Barnutiu's speeches: „O tocmeală de ruşine şi o lege nedreaptă”, Blaj, februarie, 1842; "Săborul cel mare al Episcopiei Făgăraşului", Blaj, decembrie 1842; Proclamaţia din 24/25 martie 1848; „Manifestul românilor transilvăneni”; „Discursul de la 2/14 mai 1848, rostit în Catedrala din Blaj".

[7] Bărnuţiu Simion, „Dreptulu naturale publicu”, Iaşi: Tipariulu Tribunei Române, 1870, p. 1.

[8] Bărnuţiu, Simion, „O tocmeală de ruşine şi o lege nedreaptă”, în Chindriş, Ioan, „Simion Bărnuţiu. Suveranitate naţională şi integrare europeană”, Cluj- Napoca, 1998, p.46.

[9] Bărnuţiu Simion, „Dreptulu naturale publicu”, Iaşi, 1870, p. 102.

[10] Ibidem, p. 7.

[11] Ibidem, p. 25.

[12] Bărnuţiu, Simion, „Dreptulu publicu alu românilor”, Iaşi, 1867, p. 2.

[13] Bărnuţiu, Simion , „Dreptulu naturalu publicu”, p. 90.

[14] Pandrea, Petre, „Filosofia politico-juridică a lui Simion Bărnuţiu”, Bucureşti, România Press, 2007, p. 156.

[15] Plămădeală, Antonie, „Simion Bărnuţiu în epocă şi în vecii vecilor”, în Plămădeală, Antonie, „Dascăli de cuget şi simţire românească”, Editura Institutului Biblic şi de Misiune al Bisericii Ortodoxe Române”, Bucureşti, 1981, p. 317.

[16] Roşca, D.D., „Europeanul Bărnuţiu”, in „Oameni şi climate”, Cluj: Editura Dacia, 1971, p.99.

[17] Bărnuţiu signed part of his published papers with the mention of his scientific title of "doctor in law, professor of natural law, of ethnicities law, of Romanians'public law and of philosophy at the University of Iaşi" - see Natural Public Law, the title page.

[18] See Appendix XIX named "Bărnuţiu's Course in 1859 - 1860", in Bogdan - Duică, G., "Simion Bărnuţiu’s Life and Ideas", Bucureşti: Cultura Naţională, 1924, p.244.

[19] The translations have been made from the works of some important professors of Law from Germany - Wilhelm Traugott Krug and Carl von Rotteck, acknowledged in the Western academic environment, holders of the highest level scientific and academic titles.

[20] Idem, pp. 186-187. 